\title{
UPAYA MENINGKATKAN KINERJA GURU MELALUI KEGIATAN PELATIHAN PENYUSUNAN PROPOSAL PENELITIAN TINDAKAN KELAS (PTK) PADA GURU SDN 17 NANGA JETAK KECAMATAN DEDAI KABUPATEN SINTANG
}

\author{
Jarno \\ SDN 17 Nanga Jetak, Dinas Pendidikan Kabupaten Sintang \\ E-mail: dirgajarno45@gmail.com
}

\begin{abstract}
PTK can be directly used to improve the quality of learning in the desired class. This Classroom Action Research (CAR) has a goal which is to improve or enhance continuous learning that focuses on the fulfillment of the educational professional mission carried out by the teacher. The purpose of this study is to improve teacher performance through training on class action proposals (PTK) in 17 Nanga Jetak Elementary School teachers, Dedai District, Sintang District. The research method used is a school action research (PTS). Based on the results in cycle 1 that showed 10 teachers who attended training at PTS 6 teachers or $60 \%$ had good performance, followed by 4 teachers or $40 \%$ had adequate performance, while in cycle II teachers improved better results with the results showing 10 from 10 teachers who participated in the training made learning media in higher education 7 teachers or $70 \%$ had very good performance, and as many as 3 teachers or $30 \%$ of teachers had good performance. Thus it can be denied the implementation of school actions taken can improve the performance of 17 Nanga Jetak State Teachers, Dedai District, Sintang District..
\end{abstract}

Keywords: Teacher Performance, Training, Classroom Action Research (CAR) 


\begin{abstract}
Abstrak
PTK dapat langsung dimanfaatkan untuk meningkatkan atau memperbaiki kualitas pembelajaran di dalam kelas guru yang bersangkutan. Penelitian Tindakan Kelas (PTK) tersebut memiliki tujuan yaitu untuk memperbaiki atau meningkatkan praktik pembelajaran secara berkesinambungan yang pada dasarnya melekat penunaian misi profesional kependidikan yang diemban oleh guru.Tujuan dari penelitian ini meningkatkan kinerja guru melalui kegiatan pelatihan penyusunan proposal penelitian tindakan kelas (PTK) pada guru SD Negeri 17 Nanga Jetak Kecamatan Dedai Kabupaten Sintang. Metode penelitian yang dilakukan merupakan penelitian tindakan sekolah (PTS). Berdasarkan hasil tindakan pada siklus 1 yang menunjukan bahwa dari 10 Guru yang mengikuti pelatihan dalam PTS terdapat 6 guru atau 60\% memiliki kinerja baik, selanjutnya terdapat 4 guru atau $40 \%$ memiliki kinerja yang cukup, sedangkan pada siklus II kinerja guru meningkat menjadi lebih baik dengan hasil menunjukan bahwa dari 10 Guru yang mengikuti pelatihan pembuatan media pembelajaran dalam PTS terdapat 7 guru atau $70 \%$ memiliki kinerja sangat baik, dan sebanyak 3 guru atau 30\% guru memiliki kinerja yang baik. Dengan demikian dapat disimpulkan bahwa pelaksanaan tindakan sekolah yang dilakukan dapat meningkatkan kinerja Guru Negeri 17 Nanga Jetak Kecamatan Dedai Kabupaten Sintang.
\end{abstract}

Kata Kunci: Kinerja Guru, Pelatihan, Penelitian Tindakan Kelas (PTK). 


\section{A. Pendahuluan}

Sebagaimana tercantum dalam Pasal 19 ayat (3) PP RI No 19 Tahun 2005, dijelaskan bahwa setiap satuan pendidikan melakukan perencanaan proses pembelajaran, pelaksanaan proses pembelajaran, penilaian hasil pembelajaran, dan pengawasan proses pembelajaran untuk terlaksananya proses pembelajaran yang efektif danefisien. Disisi lain, keberhasilan pelaksanaan proses pendidikan di tingkat satuan pendidikan merupakan hal yang berhubungan erat dengan guru sebagai pihak yang secara langsung melaksanakan proses pendidikan di sekolah.

Arti penting peran guru terhadap kualitas output pendidikan ini tersirat dalam Undang-Undang Nomor 14 Tahun 2005 tentang Guru dan Dosen pada Pasal 4 dinyatakan, bahwa kedudukan guru sebagai tenaga profesional berfungsi untuk meningkatkan martabat dan peran guru sebagai agen pembelajaran, yang sekaligus berfungsi untuk meningkatkan mutu pendidikan nasional. Hal ini menunjukkan bahwa guru memiliki peran yang penting dalam pelaksanaan pendidikan di tingkat satuan pendidikan, sehingga diarahkan menjadi tenaga profesional bertumpu pada tujuan meningkatnya kualitas output pendidikan. kualitas pendidik di jenjang anak usia dini, harus senantiasa dioptimalkan pelayannnya yang berorientasi pada peningkatan kualitas.

Usaha-usaha untuk mempersiapkan guru menjadi profesional telah banyak dilakukan. Kenyataan menunjukkan bahwa tidak semua guru memiliki kinerja yang baik dalam melaksanakan tugasnya. "Hal itu ditunjukkan dengan kenyataan (1) guru sering mengeluh kurikulum yang berubahubah, (2) guru sering mengeluhkan kurikulum yang syarat dengan beban, (3) seringnya siswa mengeluh dengan cara mengajar guru yang kurang menarik, (4) masih belum dapat dijaminnya kualitas pendidikan sebagai mana mestinya" (Imron, 2000:5).

Berdasarkan kenyataan begitu berat dan kompleksnya tugas serta peran guru tersebut, perlu diadakan supervisi atau pembinaan terhadap guru secara terus menerus untuk meningkatkan kinerjanya. Kinerja guru perlu ditingkatkan agar usaha membimbing siswa untuk belajar dapat berkembang.

Proses pengembangan kinerja guru terbentuk dan terjadi dalam kegiatan belajar mengajar di tempat mereka bekerja. Selain itu kinerja guru dipengaruhi oleh hasil pembinaan dan supervisi kepala sekolah" (Pidarta, 1992:3). Pada pelaksanaan Kurikulum 2013 menuntut kemampuan baru pada guru untuk dapat mengelola proses pembelajaran secara efektif dan efisien. Tingkat produktivitas 
sekolah dalam memberikan pelayanan-pelayanan secara efisien kepada pengguna (peserta didik, masyarakat) akan sangat tergantung pada kualitas gurunya yang terlibat langsung dalam proses pembelajaran dan keefektifan mereka dalam melaksanakan tanggung jawab individual dan kelompok.

Direktorat Pembinaan SD/MIN (2008:3) menyatakan "kualitas pendidikan sangat ditentukan oleh kemampuan sekolah dalam mengelola proses pembelajaran, dan lebih khusus lagi adalah proses pembelajaran yang terjadi di kelas, mempunyai andil dalam menentukan kualitas pendidikan konsekuensinya, adalah guru harus mempersiapkan (merencanakan) segala sesuatu agar proses pembelajaran di kelas berjalan dengan efektif'.Hal ini berarti bahwa guru sebagai fasilitator yang mengelola proses pembelajaran di kelas mempunyai andil dalam menentukan kualitas pendidikan. Konsekuensinya adalah guru harus mempersiapkan (merencanakan) segala sesuatu agar proses pembelajaran di kelas berjalan dengan efektif.

Kinerja dalam pengertiannya disebut juga sebagai prestasi kerja atau dalam bahasa inggris disebut dengan performance. Kinerja merupakan hasil atau tingkat keberhasilan seseorang secara keseluruhan selama periode tertentu di dalam melaksanakan tugas dibandingkan dengan berbagai kemungkinan, seperti standar hasil kerja, target atau sasaran atau kriteria yang telah ditentukan terlebih dahulu dan telah disepakati bersama. Guru yang memiliki kinerja yang baik sering disebut sebagai guru yang profesional (Jalal \& Supriadi, 2001).

Kinerja guru yang profesional seharusnya dimiliki oleh setiap pendidik karena melalui kondisi tersebut dapat diperoleh pendidikan yang mampu membentuk manusia berkualitas. Untuk mewujudkannya dapat dilakukan dengan ketersediaan pendidik yang berkualitas. Berbagai upaya sudah dilakukan untuk menghasilkan pendidik yang memiliki kinerja berkualitas. Salah satu upaya tersebut berasal dari pemerintah dengan menetapkan perogram sertifikasi guru yang diatur oleh Undang-Undang RI Nomor 20 Tahun 2003 tentang Sistem Pendidikan Nasional, Undangundang RI Nomor 14 Tahun 2005 tentang Guru dan Dosen, dan Peraturan Pemerintah RI Nomor 19 Tahun 2005 tentang Standar Nasional Pendidikan menyatakan guru adalah pendidik profesional.

PTK dapat langsung dimanfaatkan untuk meningkatkan atau memperbaiki kualitas pembelajaran di dalam kelas guru yang bersangkutan. Penelitian Tindakan Kelas (PTK) tersebut memiliki tujuan yaitu untuk memperbaiki atau meningkatkan praktik pembelajaran secara berkesinambungan yang pada dasarnya melekat penunaian misi profesional kependidikan yang diemban oleh guru. Dengan kata lain, tujuan utama PTK adalah untuk 
perbaikan dan peningkatan layanan profesional guru. Di samping itu, sebagai tujuan PTK adalah untuk meningkatkan budaya meneliti bagi guru (Widayati, 2012).

Seperti yang telah dijelaskan oleh Widayati (2012) bahwasannya PTK nantinya diharapkan meningkatkan kompetensi guru. Kompetensi ini perlu dilaksanakan secara sadar dan sistematik di kelas. Menurut penjelasan Sukanti (2008, pp. 1-11) bahwasannya tidak semua kompetensi dapat ditingkatkan oleh seorang tetapi hanya subkompetensi tertentu saja seperti: (1) memahami gaya belajar dan kesulitan belajar peserta didik, (2) menguasai teori dan prinsip belajar serta pembelajaran yang mendidik, (3) mengembangkan kurikulum yang mendorong keterlibatan peserta didik dalam pembelajaran, (4) merancang pembelajaran yang mendidik, (5) melaksanakan pembelajaran yang mendidik, (6) mengevaluasi proses dan hasil pembelajaran, (7) mengevaluasi kinerja sendiri, (8) mengembangkan diri secara berkelanjutan, (9) menguasai substansi bidang studi dan metodologi keilmuannya, (10) menguasai struktur bidang studi dan materi kurikulum bidang studi, (11) menguasai dan memanfaatkan teknologi informasi dan komunikasi dalam pembelajaran, mengorganisasikan materi kurikulum bidang studi, (13) meningkatkan kualitas pembelajaran.

Sebagai seorang guru dalam melakukan proses belajar mengajar tentunya ada kendala atau masalah yang dihadapi. Upaya yang dapat dilakukan dalam mengatasi permasalahan proses kegiatan mengajar dapat dilakukan dengan melakukan Penelitian Tindakan Kelas (PTK). Dengan melakukan penelitian tindakan guru dapat segera mengidentifikasi penyebab faktorfaktor yang dapat menimbulkan permasalahan dan segera dapat menemukan solusi dari tindakan yang diterapkan. Di kabupaten malang dengan luas area yang sangat luas dan guru yang relatif cukup banyak tentunya sangat potensial untuk melakukan penelitian tindakan kelas.

Tujuan utama dari kegiatan ini adalah untuk meningkatkan kemampuan guru SD Negeri 17 Nanga Jetak Kecamatan Dedai Kabupaten Sintang. Manfaat yang diharapkan dari kegiatan ini adalah: (1) Bisa membuat laporan-laporan PTK yang dapat dijadikan bahan panduan bagi para pendidik (guru) untuk meningkatkan kulitas pembelajaran. Selain itu hasil-hasil PTK yang dilaporkan dapat dijadikan sebagai bahan artikel ilmiah atau makalah untuk berbagai kepentingan antara lain disajikan dalam forum ilmiah dan dimuat di jurnal ilmiah, (2) Menumbuhkembangkan kebiasaan, budaya, dan atau tradisi meneliti dan menulis artikel ilmiah di kalangan pendidik. Hal ini ikut mendukung professionalisme dan karir pendidik, (3) Mewujudkan kerja sama, kaloborasi, dan atau sinergi antarpendidik dalam satu 
sekolah atau beberapa sekolah untuk bersama-sama memecahkan masalah dalam pembelajaran dan meningkatkan mutu pembelajaran, (4) Meningkatkan kemampuan pendidik dalam upaya menjabarkan kurikulum atau program pembelajaran sesuai dengan tuntutan dan konteks lokal, sekolah, dan kelas. Hal ini turut memperkuat relevansi pembelajaran bagi kebutuhan peserta didik, (5) Memupuk dan meningkatkan keterlibatan, kegairahan, ketertarikan, kenyamanan, dan kesenangan siswa dalam mengikuti proses pembelajaran di kelas. Di samping itu, hasil belajar siswa pun dapat meningkat, (6) Mendorong terwujudnya proses pembelajaran yang menarik, menantang, nyaman, menyenangkan, serta melibatkan siswa karena strategi, metode, teknik, dan atau media yang digunakan dalam pembelajaran demikian bervariasi dan dipilih secara sungguh-sungguh.

Berdasarkan paparan di atas maka perlu dilakukan penelitian dengan judul "Upaya meningkatan Kinerja Guru Melalui Kegiatan Pelatihan Penyusunan Proposal Penelitian Tindakan Kelas (PTK) Pada Guru Sdn 17 Nanga Jetak Kecamatan Dedai Kabupaten Sintang"

\section{B. Metode}

Metode yang digunakan dalam penelitian ini adalah metode Penelitian Tindakan Sekolah (PTS). Penelitian ini dilakukan dalam tiga tahapan, yaitu persiapan, pelaksanaan dan evaluasi dan refleksi, dan dilakukan minimal dalam dua siklus. Pada tahap persiapan dibuat dibuat skenario kegiatan, jadwal waktu, tempat serta sarana pendukung lainnya seperti lembar observasi, serta angket. Lokaso Penelitian dilakukan di SDN 17 Nanga Jetak Kecamatan Dedai Kabupaten Sintang.

Teknik analisis data dilakukan terhadap hasil media pembelajaran guru sebagai data awal kemampuan guru dan hasil observasi yang dilakukan selama proses pembinaan akan dianalisis secara deskriptif untuk mengukur keberhasilan proses pembinaan sesuai dengan tujuan penelitian tindakan sekolah ini. Adapun PTS ini dikatakan berhasil apa bila lebih dari $50 \%$ guru masuk dalam kategori sangat baik.

Sumber data yang dimanfaatkan dalam penelitian ini terdiri dari: (1). informan; orang yang dipandang mengetahui permasalahan yang akan diteliti dan bersedia untuk memberikan informasi kepada peneliti berupa kata-kata. Informan dalam penelitian ini adalah siswa-siswi SMA-SMK, kepala sekolah, orang tua dan mahasiswa pelaksana kegiatan bakti mahasiswa. (2). Peristiwa dan lokasi; penelitian kualitatif tidak lepas dari wawancara dan obervasi lapangan

\section{Pembahasan dan Hasil}

\section{Pra Sklus}

.Penelitian tindakan yang dilakukan di SDN 17 Nanga 
Jetak Kecamatan Dedai Kabupaten Sintang ini dilakukan oleh kepala sekolah melalui tehnik supervisi akademik secara berkelompok sebagai upaya untuk meningkatkan kemampuan/kompetensi pedagogik guru dalam membuat media pembelajaran. Penelitian dilakukan terhadap 10 orang guru yang memiliki latar belakang pendidikan keguruan akan tetapi kurang kompeten dalam menyusun proposal Penelitian Tindakan Kelas
(PTK) yang baik. Dengan demikian permasalahan dalam penelitian tindakan ini difokuskan pada peningkatan kinerja guru melalui pelatihan penyusunan proposal PTK.

Dari data awal yang diperoleh pada kegiatan penelitian, terlihat bahwa sebagian besar guru masih kesulitan merancang proposal tindakan kelas sehingga kinerja guru pun masih rendah. Perolehan hasil belajar Pra Siklus disajikan dalam tabel berikut.

\begin{tabular}{|c|c|c|c|c|c|c|c|c|c|}
\hline \multirow{2}{*}{ Guru } & \multicolumn{6}{|c|}{ Penilaian } & \multirow{2}{*}{ Jumlah } & \multirow{2}{*}{$\begin{array}{l}\text { Total } \\
\text { Nilai }\end{array}$} & \multirow{2}{*}{ Keterangan } \\
\hline & 1 & 2 & 3 & 4 & 5 & 6 & & & \\
\hline Guru 1 & 1 & 2 & 1 & 1 & 1 & 1 & 7 & 29 & Kurang \\
\hline Guru 2 & 3 & 2 & 1 & 1 & 1 & 1 & 9 & 38 & Cukup \\
\hline Guru 3 & 3 & 1 & 1 & 1 & 2 & 1 & 9 & 38 & Cukup \\
\hline Guru 4 & 2 & 1 & 1 & 1 & 1 & 1 & 7 & 29 & Cukup \\
\hline Guru 5 & 3 & 1 & 1 & 1 & 1 & 1 & 8 & 33 & Cukup \\
\hline Guru 6 & 2 & 1 & 1 & 2 & 2 & 1 & 9 & 38 & Cukup \\
\hline Guru 7 & 2 & 1 & 1 & 2 & 1 & 1 & 8 & 33 & Cukup \\
\hline Guru 8 & 2 & 1 & 3 & 1 & 1 & 2 & 10 & 42 & Cukup \\
\hline Guru 9 & 2 & 1 & 1 & 1 & 1 & 2 & 8 & 33 & Cukup \\
\hline Guru 10 & 2 & 1 & 1 & 2 & 1 & 2 & 9 & 38 & Cukup \\
\hline \multicolumn{8}{|c|}{ Rata-rata } & 34,03 & Cukup \\
\hline
\end{tabular}

Nilai Keseluruhan pada Tahap Prasiklus

\begin{tabular}{l|l|r|r}
\hline \multicolumn{1}{c|}{ Kategori } & Rentang Nilai & Frekuensi & Presentase \\
\hline Sangat Baik & $85-100$ & 0 & $0 \%$ \\
\hline Baik & $70-84$ & 0 & $0 \%$ \\
\hline Cukup & $55-69$ & 9 & $90 \%$ \\
\hline Kurang & $0-54$ & 1 & $10 \%$ \\
\hline \multicolumn{2}{c}{ Jumlah } & 10 & $100 \%$ \\
\hline
\end{tabular}

Berdasarkan hasil penelitian menunjukan bahwa dari 10 Guru yang mengikuti pelatihan dalam PTS terdapat 1 guru atau $10 \%$ memiliki kinerja kurang, selanjutnya terdapat 9 guru atau 90\% memiliki kompetensi yang cukup, dan tidak ada guru yang memiliki kemampuan 
baik. Adapun hasil tersebut dapat dilihat pada grafik di bawah ini:

\section{Hasil Penilaian Kinerja Guru pada Tahap Prasiklus Hasil Penilaian Prasiklus}

Sangat Baik

naik

Cukup

$90 \%$

\section{Tahap Siklus 1}

Adapun hasil tersebut dapat dilihat pada diagram kemampuan guru pada awal tindakan siklus 1 sebagai berikut.

Tabel 4.3

Kemampuan Guru Pada Tahap Siklus I

\begin{tabular}{|c|c|c|c|c|c|c|c|c|c|}
\hline \multirow{2}{*}{ Guru } & \multicolumn{6}{|c|}{ Penilaian } & \multirow{2}{*}{ Jumlah } & \multirow{2}{*}{$\begin{array}{l}\text { Total } \\
\text { Nilai }\end{array}$} & \multirow{2}{*}{ Keterangan } \\
\hline & 1 & 2 & 3 & 4 & 5 & 6 & & & \\
\hline Guru 1 & 2 & 2 & 2 & 1 & 3 & 3 & 13 & 54 & Cukup \\
\hline Guru 2 & 3 & 2 & 1 & 3 & 3 & 1 & 13 & 54 & Cukup \\
\hline Guru 3 & 3 & 1 & 3 & 1 & 2 & 4 & 14 & 58 & Baik \\
\hline Guru 4 & 3 & 1 & 1 & 3 & 3 & 3 & 14 & 58 & Baik \\
\hline Guru 5 & 3 & 2 & 3 & 1 & 3 & 1 & 13 & 54 & Cukup \\
\hline Guru 6 & 2 & 1 & 2 & 2 & 3 & 3 & 13 & 54 & Cukup \\
\hline Guru 7 & 3 & 2 & 1 & 2 & 3 & 1 & 12 & 50 & Cukup \\
\hline Guru 8 & 2 & 2 & 3 & 1 & 2 & 3 & 13 & 54 & Cukup \\
\hline Guru 9 & 3 & 2 & 1 & 2 & 3 & 3 & 14 & 58 & Baik \\
\hline Guru 10 & 2 & 3 & 2 & 3 & 3 & 2 & 15 & 63 & Baik \\
\hline \multicolumn{8}{|c|}{ Rata-Rata } & 55,56 & Cukup \\
\hline
\end{tabular}

Nilai Keseluruhan pada Tahap Siklus I

\begin{tabular}{l|l|r|r}
\hline Kategori & Rentang Nilai & Frekuensi & Presentase \\
\hline $\begin{array}{l}\text { Sangat } \\
\text { Baik }\end{array}$ & $85-100$ & 0 & $0 \%$ \\
\hline Baik & $70-84$ & 0 & $40 \%$ \\
\hline Cukup & $55-69$ & 6 & $60 \%$ \\
\hline
\end{tabular}




\begin{tabular}{r|rr|r|r}
\hline Kurang & $0-54$ & 0 & $0 \%$ \\
\hline \multicolumn{3}{c}{ Jumlah } & 10 & $100 \%$ \\
\hline \multicolumn{3}{c}{ masukan dalam } & perencanaan
\end{tabular}

Berdasarkan pada data tersebut, maka dilakukan tindakan pada siklus 1 dengan titik berat pada kesulitan-kesulitan yang dihadapi, dengan cara memberikan penjelasan contoh-contoh yang relevan. Pada akhir kegiatan siklus 1 diperoleh peningkatan kemampuan guru sebagai berikut: Berikut ini grafik peningkatan hasil setelah siklus 1 menunjukan bahwa dari 10 Guru yang mengikuti pelatihan dalam PTS terdapat 6 guru atau $60 \%$ memiliki kinerja cukup, selanjutnya terdapat 4 guru atau $40 \%$ memiliki kinerja yang baik, dan tidak ada guru yang kemampuan yang kurang.

Melihat hasil yang diperoleh pada refleksi kegiatan siklus 1, maka dilakukan tindakan penelitian pada siklus 2 dengan menggunakan hasil tindakan siklus 1 sebagai bahan kegiatan siklus ini dengan tujuan untuk lebih meningkatkan dan menguatkan kemampuan guru dalam membuat media pembelajaran hingga bisa mencapai hasil minimal $70 \%$.

\section{Tahap Silus II}

Dalam pelaksanaan siklus II kinerja guru lebih baik dibandingkan siklus I. Berdasarkan hasil penelitian menunjukan bahwa dari 10 Guru yang mengikuti pelatihan penyusunan proposal PTK dalam PTS terdapat 7 guru atau $70 \%$ memiliki kemampuan sangat baik dalam membuat media pembelajaran, dan sebanyak 3 guru atau $30 \%$ guru memiliki kemampuan yang baik. Adapun hasil tersebut dapat dilihat pada diagram kemampuan guru pada awal tindakan siklus II sebagai berikut :

Kinerja Guru Pada Tahap Siklus II

\begin{tabular}{|c|c|c|c|c|c|c|c|c|c|}
\hline \multirow{2}{*}{ Guru } & \multicolumn{6}{|c|}{ Penilaian } & \multirow{2}{*}{ Jumlah } & \multirow{2}{*}{$\begin{array}{l}\text { Total } \\
\text { Nilai }\end{array}$} & \multirow{2}{*}{ Keterangan } \\
\hline & 1 & 2 & 3 & 4 & 5 & 6 & & & \\
\hline Guru 1 & 4 & 4 & 3 & 2 & 3 & 3 & 19 & 79 & Baik Sekali \\
\hline Guru 2 & 4 & 3 & 2 & 3 & 3 & 2 & 17 & 71 & Baik \\
\hline Guru 3 & 4 & 4 & 3 & 2 & 2 & 4 & 19 & 79 & Baik Sekali \\
\hline Guru 4 & 3 & 3 & 4 & 3 & 4 & 3 & 20 & 83 & Baik Sekali \\
\hline Guru 5 & 4 & 4 & 3 & 3 & 4 & 3 & 21 & 88 & Baik Sekali \\
\hline Guru 6 & 4 & 4 & 2 & 2 & 3 & 3 & 18 & 75 & Baik \\
\hline Guru 7 & 3 & 3 & 4 & 3 & 3 & 3 & 19 & 79 & Baik Sekali \\
\hline Guru 8 & 4 & 3 & 3 & 2 & 4 & 3 & 19 & 79 & Baik Sekali \\
\hline Guru 9 & 4 & 2 & 3 & 4 & 3 & 3 & 19 & 79 & Baik Sekali \\
\hline Guru 10 & 4 & 3 & 2 & 3 & 3 & 2 & 17 & 71 & Baik \\
\hline \multicolumn{8}{|c|}{ Rata-Rata } & 79,17 & Baik Sekali \\
\hline
\end{tabular}

Nilai Keseluruhan pada Tahap Siklus II

\begin{tabular}{l|l|l|l}
\hline Kategori & Rentang Nilai & Frekuensi & Presentase \\
\hline
\end{tabular}




\begin{tabular}{l|l|r|r}
\hline $\begin{array}{l}\text { Sangat } \\
\text { Baik }\end{array}$ & $85-100$ & 7 & $70 \%$ \\
\hline Baik & $70-84$ & 3 & $30 \%$ \\
\hline Cukup & $55-69$ & 0 & $0 \%$ \\
\hline Kurang & $0-54$ & 0 & $0 \%$ \\
\hline \multicolumn{2}{r|}{ Jumlah } & 10 & $100 \%$ \\
\hline
\end{tabular}

Berdasarkan hasil penelitian menunjukan bahwa dari 10 Guru yang mengikuti pelatihan dalam PTS terdapat 7 guru atau $70 \%$ memiliki kinerja sangat baik, selanjutnya terdapat 3 guru atau $30 \%$ memiliki kinerja baik, dan tidak ada guru yang memiliki kemampuan kurang.

Pada tahap refleksi siklus kedua, peneliti melakukan evaluasi bersama guru yang disupervisi terhadap hasil observasi di siklus kedua. Dari data yang dikumpulkan sebelum dan selama proses penelitian tindakan, kita dapat melihat adanya peningkatan kemampuan guru pada masing-masing komponen perencanaan pembelajaran menunjukan bahwa perolehan hasil penelitian dalam kegiatan penelitian tindakan sekolah ini, dapat disimpulkan bahwa kegiatan pelatihan penyusunan proposal penelitian tindakan kelas (PTK), 10 orang guru yang memiliki permasalahan kinerjanya. Berdasarkan hasil yang telah dijelaskan menunjukan bahwa tindakan yang dilakukan dalam meningkatkan kinerja guru melalui kegiatan PTS dikatakan berhasil.

Hal tersebut berdasarkan hasil tindakan pada siklus 1 yang menunjukan bahwa dari 10 Guru yang mengikuti pelatihan dalam PTS terdapat 6 guru atau $60 \%$ memiliki kinerja baik, selanjutnya terdapat 4 guru atau $40 \%$ memiliki kinerja yang cukup, sedangkan pada siklus II kinerja guru meningkat menjadi lebih baik dengan hasil menunjukan bahwa dari 10 Guru yang mengikuti pelatihan pembuatan media pembelajaran dalam PTS terdapat 7 guru atau $70 \%$ memiliki kinerja sangat baik, dan sebanyak 3 guru atau 30\% guru memiliki kinerja yang baik. Dengan demikian dapat disimpulkan bahwa pelaksanaan tindakan sekolah yang dilakukan dapat meningkatkan kinerja Guru SDN 17 Nanga Jetak Kecamatan Dedai Kabupaten Sintang.

\section{Simpulan}

Berdasarkan hasil tindakan pada siklus 1 yang menunjukan bahwa dari 10 Guru yang mengikuti pelatihan dalam PTS terdapat 6 guru atau $60 \%$ memiliki kinerja baik, selanjutnya terdapat 4 guru atau $40 \%$ memiliki kinerja yang cukup, sedangkan pada siklus II kinerja guru meningkat menjadi lebih baik dengan hasil menunjukan bahwa dari 10 Guru yang mengikuti pelatihan pembuatan media pembelajaran dalam PTS terdapat 7 guru atau $70 \%$ memiliki kinerja sangat baik, dan sebanyak 3 guru atau $30 \%$ guru 
memiliki kinerja yang baik. Dengan demikian dapat disimpulkan bahwa pelaksanaan tindakan sekolah yang dilakukan dapat meningkatkan kinerja Guru SDN 17 Nanga Jetak Kecamatan Dedai Kabupaten Sintang.

\section{Daftar Pustaka}

Amriany A., F. Yusti, P. R. Gunadi. (2004). "Iklim organisasi yang kondusif meningkatkan kedisiplinan kerja". Anima. Fakultas Psikologi Universitas Surabaya. Vol. 19 No. 2. Hlm.179-193.

Anton Wardoyo. (2011). "Pengaruh Persepsi Guru tentang Sertifikasi Guru dan Motivasi Kerja Guru terhadap Kinerja Guru di SMK 45 Wonosari Tahun Pelajaran 2009/2010”. Skripsi tidak diterbitkan. Yogyakarta: FT UNY.

Anoraga, Pandji. (1992). Psikologi Kerja. Jakarta: Rineka Cipta.

Ati Cahayani. (2003). Dasar-Dasar Organisasi dan Manajemen. Jakarta: Grasindo.

Canggih Ridha Pristian. (2011). "Pengaruh Motivasi dan Disiplin terhadap Kinerja Pegawai pada Dinas Kehutanan dan Perkebunan Kabupaten Jepara". Skripsi tidak diterbitkan. Semarang: FE UNNES.

Depdiknas. (2001). "Standar Kompetensi Dasar Guru". Jakarta: Ditjen Dikti.

Dessler, Garry. (1997). Manajemen Personalia "Teknik dan Konsep Modern”. Jakarta: Erlangga.

Ditjen Peningkatan Mutu Pendidik dan Tenaga Kependidikan.
(2008). Penilaian Kinerja Guru. Jakarta: Depdiknas.

Djemari Mardapi. (2008). Teknik Penyusunan Instrumen Tes dan Nontes. Yogyakarta: Mitra Cendikia.

Hamalik, Oemar. (2003). Guru Dalam Pendekatan

Kompetensi. Jakarta: Bumi Aksara.

Hasibuan, Malayu SP. (2005). Manajemen Sumber Daya Manusia "Edisi Revisi". Jakarta: Bumi Aksara.

Organisasi dan Motivasi "Dasar Peningkatan Produktifitas". Jakarta: Bumi Aksara.

I Wayan Siwantara. (2009). "Pengaruh Kompetensi Profesional dan Motivasi Kerja serta Iklim Organisasi terhadap Disiplin Kerja dan Kinerja Dosen Politeknik Negeri Bali”. Jurnal Politeknik Negeri Bali, Ragam (Vol. 9 No. 2 Agustus 2009). Hlm. 224-226.

Mangkupawira, Sjafri. (2001). Manajemen Sumber Daya Manusia Strategik. Jakarta: Ghalia Indonesia.

Martinis Yamin. (2006). Sertifikasi Profesi Keguruan di Indonesia. Jakarta: Gaung Persada Press.

Miftah Thoha. (1993). Perilaku Organisasi. Jakarta: Raja Grafindo Pesada.

Muhammad Surya. (2004). Bunga Rampai Guru dan Pendidikan. Jakarta: Balai Pustaka.

Mulyasa E. (2005). Menjadi Kepala Sekolah Profesional. Bandung: Remaja Rosda Karya.

(2007). Kurikulum Tingkat satuan Pendidikan. Bandung: Remaja Rosda Karya. 
(2007). Standar Kompetensi dan Sertifikasi Guru. Bandung: Remaja Rosda Karya.

Peraturan Menteri Pendidikan Nasional No. 41 tahun 2007 tentang Standar Proses untuk Satuan Pendidikan Dasar dan Menengah.

Peraturan Pemerintah No. 74 tahun 2008 tentang Guru.

Peraturan Pemerintah No. 19 tahun 2005 tentang Standar Nasional Pendidikan.

Prawirasentono, Suyadi. (1999). Manajemen Sumber Daya Manusia Kebijakan Kinerja Karyawan. Yogyakarta: BPFE UGM.

Sinungan, Muchdarsyah. (1992). Produktivitas "Apa dan
Bagaimana”. Jakarta: Bumi Aksara.

Soedijarto, Imam. (1993). Teknik Memimpin Pegawai dan Pekerja. Jakarta: Jaya Sakti.

Hani Handoko. (1994). Manajemen "Edisi 2". Yogyakarta: BPFE.

(1994).

Manajemen Personalia dan Sumber Daya Manusia. Yogyakarta: BPFE.

Triyanto. (2006). "Sertifikasi Guru dan Upaya Peningkatan Kualifikasi, Kompetensi, dan Kesejahteraan". Jakarta: Prestasi Pustaka.

Undang Undang No. 20 Tahun 2003 tentang Sistem Pendidikan Nasional.

Undang Undang No.14 tahun 2005 tentang Guru dan Dosen. 